\title{
Relationship between Ferritin and Folic Acid Levels in Pregnant Women with Newborn Weight and Head Circumference
}

\author{
Usna Maria Harahap ${ }^{1}$, Fadil Oenzil ${ }^{2}$, Desmawati ${ }^{3}$ \\ ${ }^{1}$ Midwifery Postgraduate Study Program, Medical Faculty, Andalas University, Padang \\ ${ }^{2}$ Departments of Biochemistry, Medical Faculty, Andalas University, Padang \\ ${ }^{3}$ Departments of nutrition, Medical Faculty, Andalas University, Padang
}

SUBMISSION TRACK

\section{Received:}

Final Revision:

Available Online:

\section{KEYWORDS}

Ferritin, Folic Acid, Weight, Head

Circumference

CORRESPONDENCE

Phone: 085366152563

E-mail: usnaharahap90@yahoo.co.id
A B $\mathbf{S}$ T $\mathbf{R}$ A $\mathbf{C}$ T

Iron deficiency and folic acid anemia cause decrease
in ferritin and folic acid levels that can interfere with the
intake of oxygen and nutrients to the fetus resulting in
LBW and reduced brain growth during pregnancy. The aim
of the study was to determine the relationship between
ferritin and folic acid levels in pregnant women with
newborn weight and head circumference.
This study was a cross sectional study conducted on
55 pregnant women at $37-42$ weeks who were taken by
consecutive sampling technique. The study was carried out
in the Working Area of the Puskesmas and the Regional
Health Laboratory of the Merangin Regency, and the health
laboratory of West Sumatra Province from May 25 to July
13, 2018. Test the normality with the Kolmogorov-smirnov
test and the correlation test using Pearson and Spearman.
The results showed ferritin mean 23,643 16,682
ng/ml, folic acid 14,093 $\pm 4,578$ ng/ml, newborn weight
$3047,27 \pm 399,005$ gram and head circumference
$33,02 \pm 1,163$ cm. Statistical test results showed no
correlation between ferritin levels with body weight
(r=0.063, p=0.648) and head circumference (r=0.018,
p=0.895) and folic acid levels with body weight (r=-0.036,
p=0.795) and head circumference (r=-0.098, p=0.477).
The conclusions of the study were that ferritin and
folic acid levels of pregnant women had no significant
correlation with newborn weight and head circumference.
By improving nutrition, socioeconomic, qualitative
antenatal care, initial referral of risky cases and
supplementation of iron and folic acid can reduce the
incidence of anemia.

According to the World Health Organization (WHO), approximately $56 \%$ of all women living in developing countries are estimated 
to suffer from anemia. In Africa and Asia, anemia is estimated to contribute to more than 115,000 maternal deaths and 591,000 perinatal deaths globally per year (Sudikno and Sandjaja, 2011; Sharma and Shankar, 2010).

The main causes of maternal death in Indonesia are bleeding, hypertension in pregnancy and infection. Based on the SDKI in 2012, the Maternal Mortality Rate (MMR) was 359 per $100,000 \mathrm{KH}$ and the Infant Mortality Rate (IMR) was 32 per $1000 \mathrm{KH}$ (Rajab, 2009; SDKI, 2012).

The number of maternal deaths in Jambi Province in 2014 was 53 cases and there was an increase again in 2015 to 56 cases. In 2014, Merangin Regency was ranked second in the highest number of maternal deaths after the City of Jambi (8 cases) and in 2015 ranked first in the highest number of maternal deaths (10 cases). The number of babies who died in Jambi Province was 45 cases in 2014 and the most in the District of Merangin was 10 cases. In 2015 there was an increase in the number of babies who died in Jambi Province, namely as many as 201 cases and the most widely reported were in Merangin District (37 cases) (Profil Dinas Kesehatan Provinsi Jambi, 2014 and 2015).

According to WHO standards, anemia is if the hemoglobin $(\mathrm{Hb})$ concentration in the blood is less than $11 \mathrm{~g} / \mathrm{dL}$. The National Institute for Health and Care Excellence (NICE) recommends that women be tested for anemia again at 28 weeks' gestation (Shaikh, et al, 2015). Data from the Merangin District Health Office showed the incidence of anemia in pregnant women in 2015 was $15.54 \%$ and increased in 2016 by $37.73 \%$ from 23 Puskesmas, even in one of the 23 health centers, the incidence of anemia reached $91.36 \%$.

Iron deficiency anemia (IDA) is the most common cause in all age groups with the highest prevalence in the pregnant women group, which is about $70 \%$ (Gibney, et al, 2008; Fikawati, et al, 2015). IDA can also be exacerbated by poor nutritional status, mainly associated with a deficiency of folic acid, vitamin A or B12 (Sudikno and Sandjaja, 2011). However, the most common causes are iron deficiency and folic acid (Proverawati, 2011).

Folate deficiency will cause the maturation of the erythrocyte nucleus which will cause interference in the replication of Deoxyribo Nucleic Acid (DNA) and the process of cell division. This situation will affect the performance of body cells including cells that play a role in hemoglobin synthesis. Usually folate deficiency along with iron deficiency. Therefore, iron and folic acid supplementation is recommended during pregnancy to prevent complications (Satyam and Khusbu, 2015; Chowdhury, et al, 2014; Syah, et al, 2012). At the same time, women who received iron supplements showed a higher frequency of influence and experienced a higher likelihood of elevated hemoglobin concentrations during the second trimester and third trimester of pregnancy (WHO, 2012).

Most women start their pregnancies with anemia. So, prevention should begin before pregnancy (Sharma and Shankar, 2010). In the study of Passerini, et al (2012), in North Vietnam there were iron and folic acid supplementation programs in women before pregnancy aimed at preventing the occurrence of iron deficiency anemia. In the program, the incidence of Low Birth Weight (LBW) was reduced and there was an increase in birth weight in rural Vietnam.

According to Kozuma (2009), a recent recommendation in Japan that daily supplementation of folic acid during $0.4 \mathrm{mg}$ pregnancy aims to prevent damage to the nerve tube closure, such as spina bifida in the fetus, regardless of whether anemia or not, even the US Public Health Service (UPHS ) recommend that all women of childbearing age should consume folic acid $400 \mu \mathrm{g}(0.4$ mg)/ day to prevent Neural Tube Defect (NTD) during periconseption one month before conception and one month post conception because human neural tube closes during the third week post conception (Tangkilisan and Rumbajan, 2002; Hanafiah, 2006). 
Folic acid is a B vitamin that functions in DNA synthesis. In the body reserves of folic acid are very few, ie between 5-10 $\mu \mathrm{g}$. The need for folic acid in normal women is 50-100 $\mu \mathrm{g} / \mathrm{day}$ and in pregnant women 300-400 $\mu \mathrm{g} / \mathrm{day}$. Folic acid deficiency can cause secondary infection, bleeding, fetal death in the womb, maternal death, habitual abortion, placental abruption, premature and congenital fetal abnormalities (NTD) (Tangkilisan and Rumbajan, 2002; Hanafiah, 2006).

One way to detect folic acid deficiency is to look at fetal brain growth during pregnancy which can be seen from the size of the newborn's head circumference. The results of the study by Darwanty and Antini (2011) showed a significant relationship between folic acid levels and head circumference ( $p$ 0.022) and between hemoglobin levels and head circumference ( $\mathrm{p}$ 0.025).

Based on Ahmed's research, et al (2011) in Bangladesh on 150 pregnant women grouped into group I those who gave birth to babies with low birth weight and group II those who gave birth to babies with normal birth weight concluded that serum folate levels were lower in group I and anthropometry (birth weight, body length and OFC) newborns show a positive correlation. Lower serum folate is significantly at risk of losing weight for newborns (OR 11.00, 95\% CI 4.81-25.15), lower body length (OR 3.67, 95\% CI 1.42-9, 47) and low OFC (OR 6.96, 95\% CI 2.4717.87).

Research by Fatima, et al (2017) in Sudan on 150 pregnant women in which the group population was divided into 3 groups, namely 50 were women with spontaneous preterm labor at 28-34 weeks gestation, 50 were women with LBW, and 50 were women with severe normal birth. The results showed that the prevalence of anemia in the study group was $60 \%$ in women with preterm labor (mean BB $1.5 \mathrm{~kg}$ ), $40 \%$ in women with LBW (mean BB $2.0 \mathrm{~kg}$ ) and $8 \%$ in women with severe normal birth (average BB $3.3 \mathrm{~kg}$ ). $\mathrm{Hb}$ levels were significantly lower in premature and LBW compared to normal birth weight groups with $\mathrm{p}<0.00001$. In addition, there is a positive correlation between maternal hemoglobin values and birth weight in the study population with a correlation coefficient ( $\mathrm{r}$ 0.40) and a correlation of determination ( $\mathrm{R} 0.7$ ). So the conclusion is that maternal hemoglobin levels are positively correlated with LBW from mothers who have anemia compared to mothers who do not have anemia.

Based on the study of Jiang, et al (2016) in China, 116 mothers and infants were grouped into fetal growth restriction (FGR) suitable for gestational age and large for the gestational age group. Birth weight, body length, head circumference, body mass index (BMI) and Rohrer's body index were measured from newborn babies. The results showed that folic acid levels were positively correlated with birth weight, head circumference and BMI.

Based on the data above, the researchers wanted to know the relationship between ferritin and folic acid levels in pregnant women with newborn body weight and head circumference.

\section{METHODS}

This study is an observational study with cross sectional design. This research has been carried out starting from May 25 to July 13, 2018 in the Bangko Health Center, Pematang Kandis and Sumber Agung Work Areas of Merangin Regency, Jambi Province for blood sampling of pregnant women at 3742 weeks of gestation. Merangin District Regional Health Laboratory for hemoglobin examination of pregnant women with the cyanmethemoglobin method. West Sumatra Province Health Laboratory Center Serology Section with ECLIA method for examination of ferritin and serum blood folic acid pregnant women in 55 samples of aterm pregnant women then measured the weight and head circumference of newborns in the first hour of birth.

Test for normality using the Kolmogorov-Smirnov test (sample> 50). The test results showed that the data were not normally distributed $(\mathrm{p}<0.05)$ in ferritin, 
folic acid and LK then data transformation was obtained, the results were not normally distributed on the head circumference, then using Spearman's non-parametric test and other variables using the Pearson parametric test.

\section{RESULTS}

Table 1 Characteristics of Respondents

\begin{tabular}{ccc}
\hline Characteristics & n & Mean \pm SD \\
\hline Age (years) & 55 & $26.53 \pm 5.494$ \\
Pregnant Distance (years) & 55 & $2.376 \pm 2.717$ \\
Parity & 55 & $0.93 \pm 0.979$
\end{tabular}

Based on Table 1 it can be concluded that the mean age of pregnant women in healthy reproductive age, mean gestational distance> 2 years and parity are not at risk.

Table 2 Average Hemoglobin, Ferritin, Folic Acid, Weight and Head Circumference of Newborn Babies

\begin{tabular}{ccc}
\multicolumn{3}{c}{ Babies } \\
\hline Variables & n & Mean \pm SD \\
\hline Hb $(\mathrm{g} / \mathrm{dL})$ & 55 & $11.375 \pm 2.400$ \\
Ferritin $(\mathrm{ng} / \mathrm{mL})$ & 55 & $23.643 \pm 16.682$ \\
Folic Acid $(\mathrm{ng} / \mathrm{mL})$ & 55 & $14.093 \pm 4.578$ \\
Newborn Weight (gram) & 55 & $3047,27 \pm 399.005$ \\
Head Circumference & 55 & $33.02 \pm 1.163$ \\
$(\mathrm{~cm})$ & & \\
\hline
\end{tabular}

Based on table 2 it can be concluded that the mean $\mathrm{Hb}$ levels, ferritin, folic acid of pregnant women, body weight and head circumference of newborns in the normal range.

The relationship of ferritin levels in pregnant women with newborn body weight can be seen in the following figure:

Figure 1 Scatter Plot of The Relationship between Ferritin Levels ofPregnant Women and Newborn

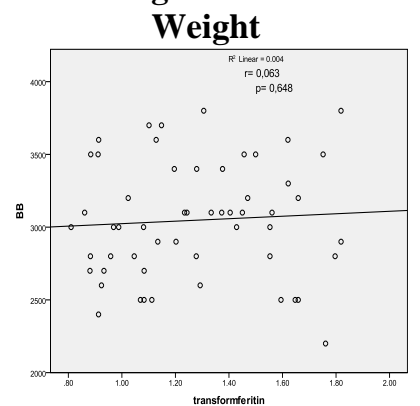

*Pearson correlation test

The relationship of ferritin levels in pregnant women with newborn head circumference can be seen in the following figure:

Figure 2 Scatter Plot of The Relationship between Ferritin Levels of pregnant Women with Newborn Head Circumference

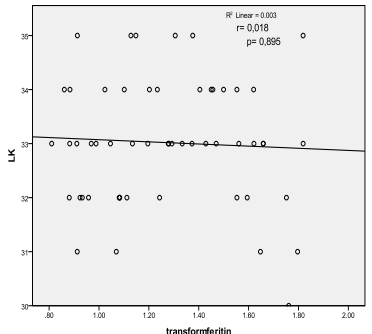

*Spearmancorrelation test

The relationship between folic acid levels in pregnant women with newborn weight can be seen in the following figure:

Figure 3 Scatter Plot of The Relationship between Folic Acid Levels of Pregnant Women and Newborn Weight

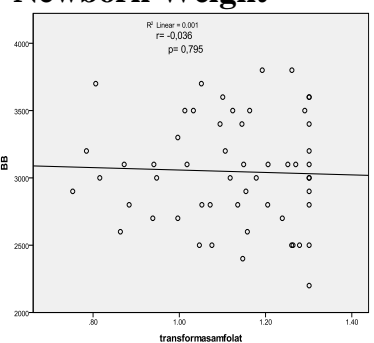

*Pearson correlation test

The relationship between folic acid levels in pregnant women with newborn head circumference can be seen in the following figure:

Figure 4 Scatter Plot of The Relationship between Folic Acid Levels of Pregnant Women with Newborn Head Circumference

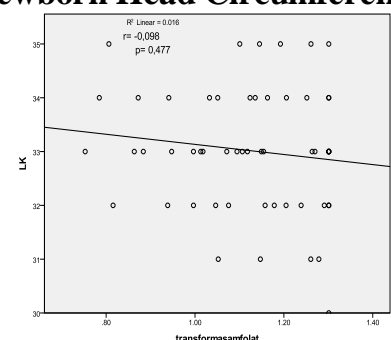

*Spearman correlation test

\section{DISCUSSION \\ Characteristics of Respondents}

In this study, the average mean age of pregnant women in healthy reproductive age, mean gestational distance> 2 years and risky parity are known.

Ahmed's research, et al (2011) on the relationship of maternal folic acid and 
vitamin B12 to newborn weight and body proportion showed that the mean age of pregnant women was $25.6 \pm 4.9$ years with a range of 17-40 years and found a parity average of 1,4 and $35.7 \%$ parity status of pregnant women is multiparous. Multi parity and short ( $<2$ years) birth spacing between pregnancies require more iron to develop fetal and placental growth.

\section{Univariat}

\section{Hemoglobin Levels}

In this study it can be seen the mean hemoglobin level in the normal range so that it does not indicate anemia $(\mathrm{Hb}<11 \mathrm{~g} / \mathrm{dl}$ in the $1 \mathrm{st}$ and 3rd trimesters, $\mathrm{Hb}<10.5 \mathrm{~g} / \mathrm{dl}$ in the second trimester) (Joseph and Nugroho, 2010).

Anemia is a condition in which low $\mathrm{Hb}$ concentrations caused by low erythrocyte production, increased erythrocyte damage (hemolysis) or excessive blood loss can occur in women of reproductive age, especially pregnant and lactating women (Departemen gizi dan kesehatan masyarakat, 2011).

Decrease in the rate of erythropoiesis, loss of erythrocytes in large numbers or hemoglobin deficiency causes the ability of blood to carry oxygen below normal (Sherwood, 2011). Cost implications for various biochemical examinations, parameters for demonstrating iron status in various studies - populations of irondeficiency anemia are measured by hemoglobin levels (Gibney, et al, 2008).

\section{Ferritin Levels}

In this study, average ferritin levels were obtained in the normal range. The ferritin serum that indicates IDA in pregnancy is $<12 \mu \mathrm{g} / \mathrm{dl}$ (Gibney, et al, 2008). Based on the research of Ahmed, et al (2011) in 150 pregnant women, the mean ferritin was $45.8 \pm 20.8 \mathrm{ng} / \mathrm{mL}$. According to Siddappa, et al (2010), the form of iron storage is ferritin. IDA is the most common cause of anemia in all age groups with the highest prevalence in the group of pregnant women.

Daily iron supplementation reduces the risk of anemia in pregnancy by $70 \%$ and
IDA by $57 \%$. Women who received iron supplements showed the frequency of more influences and experienced a higher likelihood of $\mathrm{Hb}$ concentration during the second trimester and third trimester of pregnancy (WHO, 2012).

\section{Folic Acid Levels}

The average folic acid results in this study were in the normal range. Serum levels of less than $3 \mathrm{mg} / \mathrm{mL}$ in folic acid deficiency for normal serum folic acid levels are 9-45 $\mathrm{nm} \quad(3-16 \mathrm{mg} / \mathrm{ml}$ ) (Tangkilisan and Rumbajan, 2002). In the study of Ahmed, et al (2011) in Bangladesh in 150 pregnant women obtained folate results of $5.19 \mathrm{ng} / \mathrm{ml}$ in mothers who gave birth to babies with low birth weight and folate results of $10.91 \mathrm{ng} / \mathrm{ml}$ in mothers who gave birth to babies with birth weight normal $(\mathrm{p}=0,000)$.

Folic acid is an important B vitamin that is associated with normal fetal growth and development because it acts as a coenzyme for nucleic acid synthesis and takes part in DNA replication and cell division (Ahmed, et al, 2011). This situation will affect the performance of body cells including cells that play a role in hemoglobin synthesis. Folate deficiency usually coincides with iron deficiency. Therefore, iron and folic acid supplementation is recommended during pregnancy to prevent complications (Satyam and Khushbu, 2015; Chowdhury, et al, 2014; Syah, et al, 2012).

\section{Newborn weight}

The results of the average weight of newborns in this study were in the normal range. Normal birth weight in infants is $\geq$ 2500 grams (Bickley, 2015). Based on the research of Ahmed, et al (2011) results obtained in the LBW group with a mean newborn weight $2.11 \pm 0.15 \mathrm{~kg}$ and a group of infants with normal birth weight with a mean newborn weight $2.88 \pm 0.33 \mathrm{~kg}$. Eneroth's (2011) study of anemia in infants and micronutrient status showed a mean birth weight of $2697 \pm 404$ grams.

Neonatal growth is reflected in the birth weight, body length and head circumference of the newborn. By carrying out several 
interventions during pregnancy to improve maternal nutrition has a better effect on anthropometry of newborns (Nagmoti, et al, 2015).

\section{Newborn Head Circumference}

The average head circumference of newborns in this study was in the normal range. The head circumference of normal newborns is 33-37 cm (Wibowo, 2010). Based on de $\mathrm{Sa}$, et al (2015) research on anemia in pregnancy has an impact on weight and in the development of anemia in newborns, the results of mean head circumference $(34.5 \pm 1.5 \mathrm{~cm})$ from mothers with anemia, while the average circumference results head $(34.2 \pm 2.0 \mathrm{~cm})$ from mothers who do not have anemia. In general, based on results, both anemia and non-anemia pregnancies concluded that pregnancy outcomes were adequate because they considered head circumference at birth. Based on the research of Ahmed, et al (2011), the mean results of LBW group (head circumference $31.98 \pm 1.28 \mathrm{~cm}$ ) and group of infants with normal birth weight (head circumference $35.20 \pm 1.37 \mathrm{~cm}$ ).

Head circumference reflects intracranial volume including brain growth. If the brain does not grow normally, the head will be small or vice versa. If the head doesn't grow, the brain will follow. If there is a blockage of cerebrospinal fluid flow in hydrocephalus, the head volume will increase so that the head circumference is greater than normal (Soetjiningsih and Ranuh, 2013).

\section{Relationship between Ferritin Levels of} Pregnant Women with Newborn Weight

Statistical test results in this study obtained $r=0.063$ and $p=0.648$. There was a very weak positive correlation and was not statistically significant between ferritin levels of pregnant women with newborn body weight.

According to de Sa, et al (2015), maternal anemia is considered a risk factor for pregnancy and can be a cause of anemia in newborns, in addition to being associated with higher abortion, low birth weight, prematurity, fetal death and anemia in the first year of life due to storage low iron. The results of his research showed that maternal IDA (mild to moderate) can affect the blood profile and concentration of iron on the umbilical cord of the newborn's blood but without disrupting the child's anthropometric parameters.

This study is in line with the research of Hadipour, et al (2010) on hemoglobin and serum ferritin levels of newborns in anemic Iranians in 70 pregnant women. The results showed that serum ferritin levels showed no significant relationship between maternal serum ferritin levels and anthropometry neonatal ( $p>0.001)$.

The size of the baby at birth is mainly determined by the mother. One of them is the nutritional status shown through weight, height, and BMI can be considered to predict neonatal anthropometry. In the research of Nagmoti, et al (2015), the results showed that there was a relationship between maternal BMI and weight of newborns ( $\mathrm{p}=$ 0.004).

Full-term infants born to iron-deficient women have lower serum ferritin concentrations. Iron in pregnant women increases significantly in the second and third trimesters by expanding maternal blood volume and red blood cell mass (Siddappa, et al, 2010). The average amount of iron that needs to be absorbed during pregnancy is estimated to be 840-1210 mg. This absorption requirement increases from 0.8 $\mathrm{mg} /$ day in early pregnancy to $6 \mathrm{mg} /$ day at the end of pregnancy (Fraser and Cooper, 2011).

Iron is an important and vital nutrient for many cellular activities and for the initial development of the nervous system. Thus, it is very important for intrauterine and postnatal development. Birth weight is an important factor in determining the child's survival. Therefore, children with low birth weight have a high risk of becoming sick or dead in the first year of life (de Sa, et al, 2015).

Based on the results of this study stated that there was no significant relationship between ferritin levels and newborn body weight but caused by other factors/multifactorial, namely: mothers who 
were pregnant at a young age, demographic factors, maternal biology, obstetric history, maternal morbidity during pregnancy, antenatal care and toxic exposure.

Iron deficiency usually occurs due to low iron storage before pregnancy so the growing fetus consumes a lot of inventory and takes available iron priority. This needs to be done as well as increased iron requirements continue after the birth of the baby due to blood loss and breastfeeding (Chowdhury, et al, 2014).

If a woman is anemic then it should be treated with daily iron supplementation (120 $\mathrm{mg}$ of elemental iron) and folic acid (400 mg or $0.4 \mathrm{mg}$ ) until the $\mathrm{Hb}$ concentration rises to normal (WHO, 2012).

Relationship between Ferritin Levels of Pregnant Women with Newborn Head Circumference

Statistical test results in this study obtained the value of $\mathrm{r}=0.018$ and $\mathrm{p}$ value $=$ 0.895 . There is a very weak positive correlation and is not statistically significant between ferritin levels of pregnant women with newborn head circumference.

Based on the research of de $\mathrm{Sa}$, et al (2015) obtained the average head circumference of $34.5 \pm 1.5 \mathrm{~cm}$ from mothers who experienced anemia, while the average head circumference $34.2 \pm 2.0 \mathrm{~cm}$ from mothers who did not experience anemia so that conclusions were obtained there was no significant correlation between maternal ferritin and newborn head circumference. In general, based on results, both anemia and non-anemia pregnancies concluded that pregnancy outcomes were adequate because they considered head circumference at birth.

Iron is very important for brain growth and early function in humans because it supports neuronal and glial energy metabolism, neurotransmitter synthesis and myelination. Iron deficiency during the fetal or postnatal period can alter brain structure, neurochemistry and cognitive function and cause long-term cognitive and motor impairment that cannot be corrected by iron supplementation (Siddappa, et al, 2010).
The iron supplementation given will be adequate iron reserves for the mother if she is undergoing labor by surgery or has postpartum hemorrhage and the mother will start the next pregnancy with a better iron reserve. When breastfeeding, the amount of iron that a baby can store depends on maternal iron reserves. This has a significant impact on neurological development and brain function during childhood (Fraser and Cooper, 2011).

IDA is characterized by decreased transferrin saturation and reduced ferritin or hemosiderin levels in the bone marrow resulting in a decrease in the amount of hemoglobin and red blood cell production (Syah, et al, 2012; Proverawati, 2011). Low $\mathrm{Hb}$ levels will affect the ability of the maternal system to transfer enough oxygen and nutrients to the fetus (Fraser and Cooper, 2011).

Pregnant women who suffer from nutritional anemia will give birth to an anemic baby which can cause brain dysfunction and brain growth disorders (Waryana, 2010) so that every pregnant woman should be given communication, information and education about nutrition in iron-rich pregnancies and factors can affect or inhibit iron absorption. However, dietary changes alone are not enough to correct iron deficiency in pregnancy, but iron tablets also need to be given.

The results of this study state that there is no significant relationship between ferritin levels and newborn head circumference because there are other factors that influence, namely the maternal environment (age and parity, maternal nutritional status, disease, smoking and alcohol and socioeconomic status), uteroplacental and fetal function.

Relationship between Folic Acid Levels of Pregnant Women with Newborn Weight

Statistical test results in this study obtained the value of $\mathrm{r}=-0.036$ and $\mathrm{p}=$ 0.795 . There is a very weak negative correlation and not statistically significant between folic acid levels of pregnant women with newborn body weight. 
Jiang's research, et al (2016) in China on 116 mother and baby pairs found that folic acid levels were positively correlated with birth weight. In Ahmed's research, et al (2011) it was concluded that folic acid was lower in the group of infants with low birth weight and anthropometry (birth weight, body length and OFC) of newborns showed a positive correlation, namely birth weight $(\mathrm{r}=$ $0.665, \mathrm{p}=0,000)$.

The results of this study are in line with the research of Kalem, et al (2016) that the main cause of megaloblastic anemia during pregnancy is folic acid deficiency associated with maternal complications, growth retardation, preterm birth, low birth weight, pre-eclampsia, eclampsia. The results showed that the mean infant birth weight of mothers who experienced anemia was $3225.5 \pm 392.6 \mathrm{~g}$ and the mean of mothers who did not experience anemia was $3182.0 \pm 281.2 \mathrm{~g}$ and obtained no statistically significant differences in between the two groups.

Septiyani, et al (2016) conducted a study on the relationship of folic acid intake, zinc and vitamin $\mathrm{A}$ in third trimester pregnant women on birth weight in Padang Pariaman District in 59 people showed that the relationship between consumption of folic acid and newborn body weight showed that there was no relationship between consumption of folic acid and birth weight $(p=0.161)$. Data analysis showed that the direction of the positive relationship and the strength of the relationship was very weak $(\mathrm{r}=0.131)$.

The need for folic acid in pregnant women is $300-400 \mu \mathrm{g} /$ day. Folic acid deficiency can cause secondary infection, bleeding, fetal death in the womb, maternal death, habitual abortion, placental abruption, premature, and congenital fetal abnormalities (NTD) (Tangkilisan and Rumbajan, 2002; Hanafiah, 2006).

Poor maternal folate status is associated with greater risk of LBW events. Maternal folate deficiency also causes neonatal folate deficiency and has important implications for the health of neonates and infants (Gibney, et al, 2008) so neonatal folate testing is needed for comparison with maternal folate status.

Statistically, the results of this study did not show a significant relationship between folic acid levels and newborn body weight because birth weight was influenced by various factors, namely the age of pregnant women, illness during pregnancy, pregnancy distance, hemoglobin level, socioeconomic status that would affect Nutritional status of pregnant women both consumption of macronutrients and micronutrients.

One of the target populations for vitamin supplementation is pregnant and lactating women and women of childbearing age. Prenatal vitamins are routinely given as a protection against poor diet (Dwijayanthi, et al, 2011).

\section{Relationship between Folic Acid Levels of Pregnant Women with Newborn Head Circumference}

The results of statistical tests in this study obtained the value of $r=-0.098$ and the value of $p=0.477$. There is a very weak negative correlation and not statistically significant between folic acid levels of pregnant women and the head circumference of newborns.

Jiang's research, et al (2016) in China showed that folic acid levels were positively correlated with the newborn's head circumference. In Ahmed's research, et al (2011) it was concluded that folic acid was lower in the group of infants with low birth weight and anthropometry (birth weight, body length and OFC) of newborns showed a positive correlation, namely OFC $(r=0.501$, $\mathrm{p}=0,000)$

In the research of De Graaff, et al (2017) on the relationship of maternal folic acid supplementation and folate concentration during pregnancy with the growth of fetal and pediatric heads showed that no relationship was found between maternal folate concentration and postnatal head growth in children.

Folic acid has the main function of cell growth and reproduction, hydrocarbon acid production, liver function, nucleic acid formation, protein metabolism and red blood 
cell formation (Dwijayanthi, et al, 2011). The effect of increased levels of folate (can be derived from food, through supplements or food fortification) will increase intracellular folate levels so as to facilitate DNA biosynthesis and cell division (Gibney, et al, 2008).

Damage to the structure of the central nervous system, especially in the first stage of brain growth (hyperplasia) that occurs during the womb. The vulnerable period of nerve cell growth is in the third trimester of pregnancy until about 2 years after birth. Malnutrition in the early stages causes brain development to stop the synthesis of proteins and DNA so that brain development is reduced and brain cells that are normal in size are less. The impact will be seen on the structure and function of the brain in the future life so that it affects the intellectuality of children (Soetjiningsih and Ranuh, 2013).

Various causes of folate deficiency can occur, namely inadequate diet, malabsorption, increased needs (pregnancy, lactation, malignancy, chronic inflammation, hyperthyroidism), drugs, innate enzyme deficiency, alcoholism, liver disease.

Low folate status in addition to causing congenital defects, it also has the potential for adverse outcomes for the baby or his mother. In some cases, it can lead to pregnancy complications (placental abruption, spontaneous abortion, preeclampsia, premature) and in other cases intrauterine growth retardation (Gibney, et al, 2008; Grober, 2012).

In the results of this study stated that there was no significant relationship between folic acid levels and newborn head circumference because there are other factors that influence in the form of genetic factors that affect the growth of the fetus and placenta which function to supply nutrients and oxygen to the fetus, produce hormones and growth factors which can affect the mother and fetus. Conversely, hormones and growth factors produced by the mother and fetus can also regulate placental development. Baby's head size is also related to socioeconomic status associated with nutritional intake.

In pregnancy, fetal and placental growth needs can cause folic acid deficiency if the intake is not increased (Wylie and Bryce, 2010). By increasing food intake, improving socioeconomic conditions, qualitative antenatal care by health workers, initial referral of risky cases, provision of iron supplementation and folic acid can reduce the incidence of anemia (Gaur, et al, 2015).

\section{CONCLUSION}

Ferritin and folic acid levels of pregnant women have an insignificant correlation with the weight and head circumference of the newborn baby. By improving nutrition, socioeconomic conditions, qualitative antenatal care, initial referral of risky cases and supplementation of iron and folic acid can reduce the incidence of anemia in preventing complications. 


\section{REFERENCE}

Ahmed, A. Akhter, M. Sharmin, S. Ara, S. Hoque, MM. (2011). Relationship of maternal folic acid and vitamin B12 with birth weight and body proportion of newborn. J. Dhaka National Med. Coll. Hos 2011; 18 (01): 7-11

Ali, SM. Murad, AM. Murad, AM. (2015). Effect of maternal hemoglobin on anthropometric measurements of full term newly born babies. Al-nahrain college of medicine. ISSN $1681-6579$

Almatsier, S. (2004). Prinsip dasar ilmu gizi. Jakarta: Gramedia pustaka utama

Bickley, LS. (2015). Buku ajar pemeriksaan fisik \& riwayat kesehatan edisi 11. Jakarta: EGC

Bothamley, J andBoyle, M. (2010). Patofisiologi dalam kebidanan. Jakarta: EGC

Chowdhury, S. Rahman, M. Moniruddin, ABM. (2014). Anemia in pregnancy. Medicine Today, Vol. 26, No. 01

Darwanty, J and Antini, A. (2011). Kontribusi asam folat dan kadar hemoglobin pada ibu hamil terhadap pertumbuhan otak janin. Poltekkes Kemenkes bandung. Bandung. Diakses 16 Februari 2017.

<http://ejournal.litbang.depkes.go.id/index.php/kespro/article/view/3922>

De Graaff, JS. Roza, SJ. Walstra, AW. Marroun, HE. Steegers, EA. Jaddoe, VWV, et al. (2015). Associations of maternal folic acid supplementation and folate concentrations during pregnancy with foetal and child head growth: the generation $R$ study. Eur J Nutr doi: $10.1007 / \mathrm{s} 00394-015-1058-\mathrm{z}$

De Sa, SA. Willner, E. Pareira, TAD. De Sa, S. Boaventura, GT. De Azeredo, VB. (2015). Anemia in pregnancy: impact on weight and in the development of anemia in newborn. Nutr Hosp;32(5): 2071-2079. ISSN 0212-1611

Dinas Kesehatan Kabupaten Merangin. (2015). Laporan capaian indikator program KIA tahun 2015 kabupaten merangin. Bangko: Dinas Kesehatan Kabupaten Merangin

Dinas Kesehatan Kabupaten Merangin. (2016). Laporan pencapaian indikator KIA dan gizi kabupaten merangin tahun 2016. Bangko: Dinas Kesehatan Kabupaten Merangin

Departemen gizi dan kesehatan masyarakat. (2011). Gizi dan kesehatan masyarakat. Jakarta: PT. Rajagrafindo Persada.

Dinas Kesehatan Provinsi Jambi. (2015). Profil kesehatan provinsi jambi 2014. Jambi: Dinas Kesehatan Provinsi Jambi.

Dinas Kesehatan Provinsi Jambi. (2016). Profil kesehatan provinsi jambi 2015. Jambi: Dinas Kesehatan Provinsi Jambi.

Dwijayanthi, L. Nugroho, AW. Santoso, N (eds). (2011). Ilmu Gizi menjadi sangat mudah Edisi 2. Jakarta: EGC 
Eneroth, H. (2011). Infant anemia and micronutrient status, studies of early determinants in Rural Bangladesh. Universitas Upsaliensis Uppsala. ISSN 1651-6206. ISBN 978-91554-7992-3

Fatima, E. Fatima, E. Suher, A. Eatedal, M. Reham, A. Hiba, B, et al. (2017). The correlation between maternal hemoglobin level and neonatal birth weight. Int. J of multidisciplinary and current research, vol.5

Fikawati, S. Syafiq, A. Karima, K. (2015). Gizi ibu dan bayi. Jakarta: PT. Rajagrafindo persada.

Fraser, DM and Cooper, MA (eds). (2011). Myles buku ajar bidan (Edisi 14). Jakarta: EGC

Gaur, S. Kataria, SK. Agarwal, R. (2015). A study effects of maternal anaemia on anthropometrics measurements of newborns. The pharma innovation journal 2015; 4(8): 69-71. ISSN: 2277-7695

Gibney, MJ. Margaretts, BM. Kearney, JM. Arab, L (eds). (2008). Gizi kesehatan masyarakat (Public health nutrition). Jakarta: EGC

Grober, U. (2012). Mikro-nutrien: penyelarasan metabolic, pencegahan dan terapi (micronutrients: metabolic tuning-prevention-therapy). Jakarta: EGC

Hadipour, R. Norimah, AK. Poh, BK. Firoozehchian, F. Hadipour, R. Akaberi, A. (2013). Haemoglobin and serum feritin levels in newborn babies born to anaemic Iranian women: a cross sectional study in an Iranian hospital. Pakistan journal of nutrition 9 (6): 562-566, 2010. ISSN: 1680-5194

Hanafiah, TM. (2006). Perawatan antenatal dan peranan asam folat dalam upaya meningkatkan kesejahteraan ibu hamil dan janin. Pidato Pengukuhan Jabatan Guru Besar Tetap dalam Bidang Ilmu Kebidanan dan Penyakit Kandungan pada Fakultas Kedokteran.Universitas Sumatera Utara. Medan.

Jiang, HL. Cao, LQ. Chen HY. (2016). Blood folic acid, vitamin B12 and homocysteine levels in pregnant women with fetal growth restriction. Genetics and molecular research 15 (4): gmr15048890.

Joseph and Nugroho, S. (2010). Catatan kuliah ginekologi dan obstetric (Obsgyn) untuk keperawatan dan kebidanan. Yogyakarta: Nuha Medika

Kalem, P. Benli, AR. Koroglu, M. Benli, NC. Koyuncu, M. Cesur, O, et al. (2016). The effect of ferritin, vitamin B12 and folic acid on pregnancy outcomes. Int J Clin Exp Med 2016; 9(11): 22413-22147. ISSN: 1940-5901/IJCEM0031551

Kaur, M. Chauhan, A. Manzar, MD. Rajput, MM.(2015). Maternal anaemia and neonatal outcome: a prospective study on urban pregnant women. Journal of clinical and diagnostic research. DOI: 10.7860/JCDR/2015/14924.6985

Kozuma, S. (2009). Approaches to anemia in pregnancy. Research and reviews JMAJ 52(4): 214-218. 
Nagmoti, SA. Walvekar, PR. Mallapur, MD. (2015). Association between body mass index of mother and anthropometry of newborn. Int J Med Res Health Sci 4(4): 796-798. DOI: 10.5958/2319-5886.2015.00157.5

Passerini, L. Casey, GJ. Biggs, BA. Cong, DT. Phu, LB. Phuc, TQ, et al. (2012). Increased birth weight associated with regular pre-pregnancy deworming and weekly iron-folic acid supplementation for Vietnamese women. Diakses 16 Februari 2017.

<http://journals.plos.org/plosntds/article?id=10.1371/journal.pntd.000160>

Proverawati, A. (2011). Anemia dan anemia kehamilan. Yogyakarta: Nuha Medika

Rajab, W. (2009). Buku ajar epidemiologi untuk mahasiswa kebidanan. Jakarta: EGC

Rofingatul, M. Tejayanti, T. Senewe, FP. (2010). Hubungan kematangan reproduksi dan usia saat melahirkan dengan kejadian bayi berat lahir rendah (BBLR) di Indonesia tahun 2010. Jurnal kesehatan reproduksi (ISSN 2087-703X) Vol.7, No. 2 (2016), pp. 109-118

Satyam, P and Khushbu, Y. (2015). Maternal anemia in pregnancy: An overview. Review article, Vol. 4, Issue: 3: 164-179

Septiyani, W. Lipoeto, NI. Serudji, J. (2016). Hubungan asupan asam folat, zink, vitamin A ibu hamil terhadap berat badan lahir di kabupaten padang pariaman. Jurnal kesehatan andalas 2016; 5(1)

Shaikh, S. Iftequar, S. Zaheer, Z. Khan, MM. Khan, S. (2015). An overview of anemia in pregnancy. JIPBS, Vo. 2 (2), 144-151

Sharma, JB and Shankar, M. (2010). Anemia in pregnancy. JIMSA October-December 2010, Vol. 23, No. 4

Sherwood, L. (2011). Fisiologi manusia: dari sel ke sistem. Jakarta: EGC

Siddappa, AM. Rao, R. Long, JD. Widness, JA. Georgieff, MK. (2010). The assessment of newborn iron stores at birth: a review of the literature and standards for feritin concentrations. DOI: 10.1159/000100805

Soetjiningsih and Ranuh, IGNG. (2013). Tumbuh kembang anak (Edisi 2). Jakarta: EGC

Sudikno and Sandjaja. (2011). Prevalensi dan faktor risiko anemia pada wanita usia subur di rumah tangga miskin di kabupaten tasikmalaya dan ciamis, provinsi jawa barat. Jurnal kesehatan reproduksi (ISSN 2087-703X) Vol. 7, No. 2 (2016), pp: 71-82

Survei Demografi dan Kesehatan Indonesia (SDKI). (2012). Diakses 17 Januari 2018. <http://chnrl.org/pelatihan-demografi/SDKI-2012.pdf>

Syah, MNH. Thaha, AR. Citrakesumasari. (2012). Status zat gizi mikro (besi, asam folat dan seng) dan kerusakan DNA pada anemia ibu hamil di kecamatan bontonompo dan botonompo selatan kabupaten gowa tahun 2012.Diakses 16 Maret 2017. <http://pasca.unhas.ac.id/jurnal/files/7ea95f22be12960b243855c387d29dc0.pdf> 
Tangkilisan, HA and Rumbajan, D. (2002). Defisiensi asam folat. Sari pediatric, Vol. 4, No. 1, Juni 2002: 21-25

Telatar, B. Comert, S. Vitrinel, A. Erginoz, E. Akin, Y. (2009). The effect of maternal anemia on anthropometric measurements of newborns. Saudi Med J: 409-12

Waryana. 2010. Gizi reproduksi. Yogyakarta: Pustaka Rihama.

Wibowo, T. (2010). Buku saku pelayanan kesehatan neonatal esensial; Pedoman teknis pelayanan kesehatan dasar. Jakarta: Kementerian Kesehatan RI

World Health Organization (WHO). (2012). Guideline: Daily iron and folic acid supplementation in pregnant women.

Wylie, L and Bryce, H. (2010). Manajemen kebidanan gangguan medis kehamilan dan persalinan. Jakarta: EGC 


\section{BIOGRAPHY}

The first author is a midwife. She completed the Diploma III study program in 2011 at Diploma III Midwifery High School Health Science Baiturrahim Jambi. In 2012, she continued Midwifery DIV Education at the Indonesian Ministry of Health Ministry of Health Polytechnic in Medan and completed it in 2013. In 2014, she continued her midwifery Postgraduate Study Program at medical faculty, Andalas University, Padang. She worked as a permanent midwifery lecturer at The High School Health Sciences Merangin.

The second author is a professor at The Medical Faculty, Andalas University. He completed his Bachelor of General Medicine at Andalas University in 1978, the first clinical nutrition specialist from the collegiate clinical nutrition specialist in 2004 and the philosophy of doctor biochemical nutrition at Deakin University, Australia in 1990. He completed a dissertation entitled "effect of vitamins A deficiency on glucose uptake in the rat ". He has served as Vice Dean I for Academic Affairs at the Medical Faculty, Andalas University, a flying lecturer as a visiting professor in the summer class at Nagoya City University, the dean of the Medical Faculty of Riau University, the dean of the Medical Faculty Andalas University, the Head Study Program of the Medical Malikussaleh University, Program Chair Andalas University Postgraduate Study of Biomedical Sciences, Acting Dean of the Medical Faculty, Andalas University and becoming a lecturer in biochemistry at the University of Andalas Medical Faculty until now.

The third author is a lecturer in the Department of Nutrition, Faculty of Medicine Andalas University, since 2008. She obtained a Medical Doctor (MD) degree from Andalas University. She also has a master's in clinical nutrition from University of Indonesia with a thesis on body composition and angiotensinogen levels of adult. Her current research interest is nutrition and nutrigenomic. In 2012, she received a grant to investigate the association of food intake and AGT gene polymorphism in hypertensive subject. In 2014 to 2018, she won other grants to study food intake, gene and telomere length in Minangkabau Etnicity. She also also offers undergraduate and master thesis related to nutrition and public health nutrition in all life cycles. 